
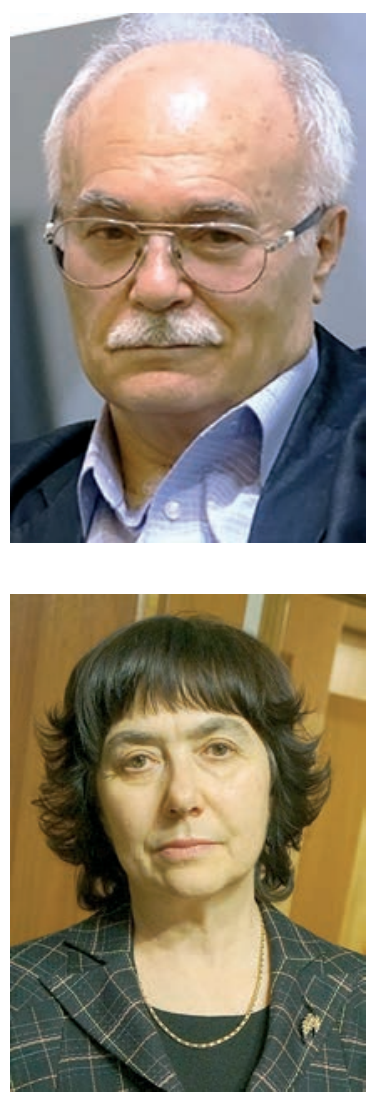

\section{Дзялошинский Иосиф Михайлович}

Доктор филологических наук, профессор

Факультет коммуникаций, медиа и дизайна, Национальный исследовательский университет «Высшая школа экономики», 101000, Российская Федерация, г. Москва, ул. Мясницкая, 20, e-mail: imd2000@yandex.ru

\section{losif M. Dzialoshinskiy}

DSc. in Philology, Professor

Faculty of Communications, Media and Design

National Research University «Higher School of Economics», 20 Myasnitskaya St., 101000, Moscow, Russian Federation, e-mail: imd2000@yandex.ru

\section{Дзялошинская Марина Иоанновна}

Кандидат филологических наук, профессор

Кафедра общественных коммуникаций и рекламы, Академия труда и социальных отношений, 119454, Российская Федерация, г. Москва, ул. Лобачевского, 90, e-mail marinika2000@yandex.ru

\section{Marina I. Dzyaloshinskaya} $\mathrm{PhD}$ in Philology, Professor

Department of Public Communications and Advertising, Academy of Labor and Social Relations, 90 Lobachevskogo St., 119454, Moscow, Russian Federation, e-mail marinika2000@yandex.ru

\title{
ЛИЧНАЯ ПОВЕСТКА ДНЯ: ИССЛЕДУЕМ ПРИОРИТЕТЫ АУДИТОРИИ
}

Аннотация. В статье в рамках рассмотрения проблемы воздействия СМИ на сознание и поведение людей (установления повестки дня) поставлен вопрос о том, существуют ли какие-то внутренние приоритеты, опираясь на которые индивид акцентирует свое внимание на тех или иных сообщениях массмедиа. Приводятся некоторые результаты пилотного исследования, проведенного авторами с целью получить ответ на данный вопрос. Делается вывод о том, что личная повестка дня, безусловно, формируется индивидом в процессе активного взаимодействия с массивом данных, предлагаемых медиа. Однако в сознании каждого человека есть довольно жесткая матрица, обеспечивающая отбор и иерархизацию сведений, поступающих из массмедиа и других источников.

Как показало исследование, личная повестка дня представляет собой значительно более сложное явление, нежели это описывается в существующих на сегодняшний день концептуальных наработках. Она не просто воспринимается индивидом из материалов СМИ. Она создается им на основе массива данных, предлагаемых массмедиа и другими 
источниками. Это означает, что любая повестка дня, которую СМИ вводят в общественный оборот, переосмысливается человеком с учетом его индивидуальной матрицы. Каждое событие, каждая проблема, заявляемые СМИ в качестве важных, получают в сознании индивида свой «индекс важности», чаще всего не совпадающий с навязываемыми индексами. Вполне вероятно, что эти информационные приоритеты выступают в роли защитных фрильтров, оберегающих индивида от манипулятивного воздействия СМИ.

Ключевые слова. Массмедиа, СМИ, повестка дня, личная повестка дня.

Финансирование. Публикация подготовлена в рамках поддержанного РГНФ научного проекта № 15-03-00514 «Экология медиасреды: проблемы безопасности и рационального использования коммуникативных ресурсов».

Информация о статье. Дата поступления 20 февраля 2017 г.; дата принятия к печати 09 октября 2017 г.; дата онлайн-размещения 30 октября 2017 г.

\section{PERSONAL AGENDA: STUDYING AUDIENCE PRIORITIES}

Abstract. In terms of considering the issue of the impact of the media on people's consciousness and behavior the article brings up the question, whether there are any internal priorities, based on which an individual focuses their attention on certain messages of the mass media. Some findings of the pilot research carried out to answer the question brought up are given in the article. A conclusion is made, that an individual forms their personal agenda in the process of active interaction with different data offered by the mass media. However, there is a fairly tight matrix in every person's mind, providing selection and hierarchization of information, received from the mass media and other sources.

The study has showed that a personal agenda is a more complex phenomenon compared to how it is described in modern conceptions. An individual does not just receive their personal agenda from the mass media. A personal agenda is created by an individual taking into account an array of information offered by the mass media and other sources. This means, that any agenda, which the mass media introduce to the public, is considered by an individual taking into account their individual matrix.

Every event, every issue, which the media state as an important one, receives its own «index of importance» in an individual's mind, and this index often does not coincide with the indexes proposed. There is a possibility that, these informational priorities play the role of security filters, protecting an individual from manipulative influence of the mass media.

Keywords. The mass media, the media, agenda, personal agenda.

Funding. The research is done with funding from The Russian Foundation for Basic Research in the framework of research project № 15-03-00514 «Ecology of the Media Environment: Issues of Security and Sustainable Use of Communicative Resources».

Article info. Received February 20, 2017; accepted October 9, 2017; available online October 30, 2017. 


\section{Введение}

Споры о том, какова степень воздействия СМИ (массмедиа) на сознание и поведение людей, продолжаются уже без малого 100 лет. Начало этим спорам было положено появлением в 1922 году работы У. Липпмана «Общественное мнение». Автор утверждал, что именно газеты формируют политические пристрастия граждан. По его мнению, человек имеет в своем сознании картину мира и приспосабливается не к своему реальному окружению, а к псевдо-окружению. Подавляющая часть мира находится для него в недоступности, поэтому он не может проверить те факты, которые приходят к нему из СМИ. Следовательно, у массмедиа есть неограниченные возможности по конструированию в сознании людей определенной картины мира [1].

Н. Лонг в 1958 г. писал «В определенном смысле газета играет определяющую роль в установлении приоритетности тематики для определенного региона. Пресса оказывает сильное воздействие на то, о чем будет говорить большинство людей, что большинство людей будет считать фактическим положением вещей, и что большинством людей будет рассматриваться как способ решения проблем» [2, р. 260].

В 1959 году в своей книге К. и Г. Лэнг писали: «СМИ направляют внимание публики на определенные вопросы <...>. Они постоянно представляют объекты, указывающие, о чем следует думать, о чем следует знать, по отношению к чему следует испытывать определенные чувства отдельным индивидам, составляющим массы». [3, р. 232]
В 1960-е годы вследствие развития телевидения появились работы, которые соотносили освещение деятельности политических персон на телевидении с созданием благоприятного мнения о них. В частности, К. и Г. Лэнг в 1966 году в работе о влиянии СМИ на выборы отмечали: массмедиа привлекают особое внимание к определенным вопросам и формируют публичные имиджи политических фигур. Они постоянно и настойчиво представляют избирателям что-либо и кого-либо и подсказывают то, что люди в своей массе должны знать об этом, что думать и что чувствовать [3].

Иная точка зрения была представлена в работах П. Лазарсфельда и ряда других исследователей, которые пришли к выводу, что средства массовой информации не являются единственным источником политического информирования. Информация, полученная избирателем по каналам СМИ, лишь усиливает уже существующие установки и ориентации, которые сформировались под воздействием таких факторов, как доход, социальный статус или профрессия, не менее важно здесь и межличностное общение [4]. В научный оборот было введено понятие «двухступенчатая модель коммуникации»: осмысление информации СМИ идет только у «лидеров мнений», самой малочисленной части аудитории, которые и передают свое понимание текущей ситуации остальным гражданам, менее интересующимся политическим процессом.

Дж. Клаппер в работе о воздействии средств массовой коммуникации выдвинул модель «минимальных эфффектов»: массмедиа редко воз- 
действуют напрямую и бессильны в сравнении с другими социальными и психологическими фракторами. Люди смотрят только те передачи и читают только те издания, которые, скорее, подтверждают, нежели изменяют их политические взгляды [5].

Возражая сторонникам концепции «минимальных эффректов» Дж. Зеллер поддержал концепцию значительного влияния СМИ на электоральные предпочтения. Он поставил вопрос: если влияние средств массовой информации минимально, то откуда берется большинство представлений людей, если не из материалов СМИ? [6]

Особую популярность на Западе, а с некоторыхпор и в России приобрела концепция установления повестки дня. Данная идея была впервые четко сорормулирована и подкреплена эмпирическими данными в ходе ставшего классическим исследования М. Маккомбса и Д. Шоу [7, р. 176-187]. Эти авторы в 1972 году обнаружили крайне высокую корреляцию между тем, какое внимание уделяли различным аспектам СМИ, и тем, какую важность придавали этим аспектам избиратели, и заново сформулировали тезис о «функции массмедиа в установлении повестки дня». М. Маккомбс и Д. Шоу ввели в практический оборот понятия «повестка дня» («agenda») - набор сюжетов и проблем, считающихся наиболее важными в тот или иной отрезок времени, и «установление повестки дня» («agenda-setting») внедрение данного набора в сознание аудитории.

Исследователи выявили внутри публичной повестки дня еще три не полностью совпадающих повестки: личную, или внутреннюю, повестку дня («intrapersonal agenda»), охватывающую наиболее важные для самого индивида социальные и политические проблемы; межличностную повестку дня («interpersonal agenda») - систему приоритетов в отношении тех проблем, которые индивид обсуждает с членами своей группы; воспринимаемую общественную повестку дня («perceivedcommunity agenda»), то есть представления индивида о том, какие проблемы воспринимаются обществом как самые важные. Выяснилось, что для формирования личной повестки дня ключевой является межличностная, а не общественная повестка дня. Считается, что данный эффект основан не на сознательном анализе всего богатства данных, которые предоставляют аудитории средства массовой информации, а на механическом запоминании тем, которые чаще всего фригурируют в СМИ. Осведомленность о тех или иных проблемах тем самым сводится к акту узнавания: индивид, сталкиваясь с проблемой, воспринимает ее как знакомую, хотя самостоятельно и не в состоянии припомнить, в чем именно она состоит.

Надо заметить, что М. Маккомбс и Д. Шоу, выпустившие в 1972 году первую статью о медийной повестке дня, очень далеко ушли от первоначальной концепции. Так, в статье «New Directionsin Agenda-Setting Theory and Research» [8] констатируется необходимость учета для понимания процесса формирования повестки дня индивидуальных особенностей журналистов и психологических факторов каждого человека. Другими словами, личная повестка дня возникает как интимный, зачастую бессознательный процесс за- 
имствования из разных источников элементов картины мира, удовлетворяющей данного индивида.

Далее последователи теории установления повестки дня разделились на два лагеря: тех, кто анализировал процесс установления повестки дня и тех, кто изучал эффректы. Первую группу при этом волновали факторы, влияющие на отбор новостей, входящих в повестку, тогда как вторые концентрировали свое внимание на том, как средства массовой информации влияют на сознание людей. Для того чтобы установить эффект воздействия повестки дня, все проблемы были разделены на «навязчивые» («obtrusive») и «ненавязчивые» («unobtrusive»). Навязчивыми были названы проблемы, знакомые людям из личного опыта, относительно которых у них есть собственное мнение. Ненавязчивые - те, о которых личного опыта у людей не существует и СМИ выступают единственным источником информации [9]. Было эмпирически доказано, что эфффект воздействия СМИ гораздо выше, когда речь идет о ненавязчивых проблемах [10].

Еще один поворот в рассмотрении формирования картины мира возникает в связи с исследованиями, посвященными конкуренции между социальными проблемами за обладание общественным вниманием [11]. В ходе этих исследований была установлено, что повестка дня складывается в процессе функционирования СМИ под влиянием внутренних правил и норм, а также при взаимодействии с агентами продвижения социальных проблем [10].

В нашу задачу не входит подробный анализ взглядов западных исследователей на проблему форми- рования повестки дня. Можно лишь констатировать, что чаще всего речь идет о факторах, связанных с общими закономерностями функционирования медиа и - иногда - о нормах и правилах, регулирующих деятельность и поведение журналистов [12; 13, 14, 15, 16 и др.].

Другой общепринятый тезис заключается в том, что возможность проникновения каких бы то ни было фактов и проблем в информационную повестку дня определяется не столько их объективным характером, сколько процессом жесткого отбора, опирающегося на скрытые от общественности критерии. В качестве таковых выделяются примерно те же критерии, о которых писал П. Бурдье: драматичность, сенсационность, зрелищность, постоянное стремление к новизне, зависимость от других средств массовой информации [17, с. 40].

Что касается российских исследователей, то они также приложили немало усилий, чтобы прояснить особенности процесса влияния на сознание и поведение различных групп аудитории посредством формирования повестки дня. Проводимые российскими учеными исследования показывают, что телевидение попрежнему остается монополистом в области формирования общественно-политической повестки дня среди населения, несмотря на растущее с каждым днем количество интернетпользователей. По данным исследования, проведенного «Левада-центром», 90\% россиян узнают новости из телевизора, большая часть зрителей доверяет всему услышанному $65 \%$ в Москве и $50 \%$ в среднем по России. К числу самых популярных каналов относятся «Первый» (82\%), 
«Россия 1» (71\%) и «НТВ» $(48 \%)$. При этом $70 \%$ населения считают, что фредеральные каналы освещают события объективно. Специалисты аналитического центра объясняют это постоянством присутствия темы в повестке дня: «Чем дольше телезрителям повторяют одну и ту же информацию, пытаются внушить определенную трактовку событий, тем больше они в нее начинают верить. <..>. В условиях отсутствия альтернативного источника информации все больше и больше людей с течением времени верит в объективность телевизионных СМИ» [18].

Обобщая, можно сказать, что теория установления, или формирования, повестки дня (Agenda-Setting Theory) описывает воздействие массмедиа, заставляющее индивидов считать некоторые явления и события, с которыми они знакомятся через прессу и телевидение, более важными, чем другие. У них в сознании происходит «воспламенение» («priming») соответствующей проблемной зоны за счет остальных зон и фрормируется соответствующая «повестка дня», то есть представление о том, что в данный момент является важным и чему следует уделять особое внимание [19].

\section{Цель исследования}

Выявить внутриличностную иерахию сорер действительности, интересующих представителей разных групп аудитории. Определить связь этой иерархии с различными социальными и психологическими особенностями индивидов.

\section{Гипотеза}

В сознании любого индивида существуют какие-то внутренние приоритеты, опираясь на которые, индивид обращает внимание на те или иные сообщения, поступающие из внешней среды.

\section{Методологические допущения}

- Пресса и другие средства массовой информации не столько отражают реальность, сколько формируют представление о ней.

- Концентрация тем в средствах массовой информации по нескольким вопросам и субъектам приводит к тому, что эти темы становятся предметом группового и межличностного общения, но не всегда затрагивают глубинные интересы людей, делающих вид, что поднимаемые СМИ проблемы их волнуют.

- Медийная повестка дня в своей основе определяется интересами элит, включая журналистскую элиту. Те, кто контролируют СМИ, решают, что должно сообщаться публике. Руководители СМИ, связанные социальными и личными отношения с разными группами элит, принимают решения по поводу того, о чем должны знать люди, о чем они должны думать и какие проблемы они должны считать более важными, а какие менее.

- Помимо важных для элит тем и проблем, в информационную повестку дня включаются темы и проблемы общего интереса, отбор которых осуществляется самими журналистами на основании критериев, о которых писал П. Бурдье: драматичность, сенсационность, зрелищность, постоянное стремление к новизне, зависимость от других средств массовой информации.

- Любое коммуникативное действие опосредовано обязательными нормами, которыми определяются 
взаимные поведенческие ожидания и которые должны пониматься и признаваться, по крайней мере, двумя субъектами, осуществляющими коммуникацию. Комплекс таких норм и правил чаще всего обозначается с помощью таких понятий, как «дискурс», «конвенция», «паттерн». Не вдаваясь в анализ различий между этими понятиями, считаем наиболее перспективным в данном контексте понятие «матрица» [20; $21 ; 22]$. Выполненный нами в предыдущих работах анализ доказывает, что такие матрицы есть как в сознании производителя медиапродуктов, так и в сознании адресатов. Совокупность знаний, ценностей и норм, характеризующих специфику коммуникации устойчивой социальной группы, предложено назвать коммуникационной матрицей [23; $24 ; 25]$.

\section{Методика}

Для получения эмпирических данных был использован метод анкетного опроса по случайной выборке. Анкеты заполнялись ре- спондентами в присутствии волонтеров - студентов старших курсов факультета коммуникаций, медиа и дизайна НИУ ВШЭ. Респондентов просили по возможности давать самые обобщенные ответы, без привязки к каким бы то ни было конкретным ситуациям. В соответствии с инструкцией анкетеры могли ответить на вопросы респондентов, но не должны были влиять на заполнение анкеты.

Опрос проводился летом 2016 года в Москве, Санкт-Петербурге, Ростове-на-Дону, Новосибирске, Нижнем Новгороде, Екатеринбурге, а также в нескольких районных центрах. Всего было опрошено 400 человек (характеристики опрошенных приведены в табл. 1, 2). Разумеется, ни количество опрошенных, ни качество выборки не позволяют считать полученные данные достаточно репрезентативными ни для России в целом, ни для какого-то конкретного региона. Они призваны лишь продемонстрировать возможность иного подхода к проблеме фрормирования повестки дня.

Характеристика респондентов, \% к числу опрошенных

\begin{tabular}{|l|c|}
\hline \multicolumn{2}{|c|}{ Пол } \\
\hline Мужской & 29,1 \\
\hline Женский & 70,9 \\
\hline \multicolumn{2}{|c|}{ Возраст } \\
\hline До 21 года & 28,2 \\
\hline 22-34 года & 49,5 \\
\hline 35-55 лет & 15,5 \\
\hline Больше 55 лет & 6,8 \\
\hline \multicolumn{2}{|c|}{ Образование } \\
\hline Среднее, среднее специальное \\
\hline Высшее (незаконченное высшее) журналистское \\
\hline
\end{tabular}


Theoretical and Practical Issues of Journalism, 2017, vol. 6, no. 4, pp. 465-481

\begin{tabular}{|c|c|}
\hline Высшее (незаконченное высшее) гуманитарное & 59,2 \\
\hline Высшее (незаконченное высшее) техническое & 19,4 \\
\hline Имею ученую степень & 1,9 \\
\hline \multicolumn{2}{|l|}{ Сфера деятельности } \\
\hline $\begin{array}{l}\text { Промышленность (в т. ч. транспорт, связь, строитель- } \\
\text { ство) }\end{array}$ & 13,7 \\
\hline Сельское хозяйство & 3,8 \\
\hline $\begin{array}{l}\text { Торговля, общепит, жилищно-коммунальное хозяйство, } \\
\text { бытовое обслуживание }\end{array}$ & 9,7 \\
\hline Здравоохранение, социальное обеспечение & 1,9 \\
\hline Образование & 18,4 \\
\hline Культура/искусство & 5,8 \\
\hline Посредничество и консультационные услуги & 2,9 \\
\hline Кредитование, фринансы и банковский бизнес & 10,7 \\
\hline Органы власти и управления & 13,6 \\
\hline Общественные организации & 1,0 \\
\hline Средства массовой информации & 2,9 \\
\hline Неработающие пенсионеры & 2,9 \\
\hline Учащиеся высших и средних учебных заведений & 22,3 \\
\hline Армия, органы правопорядка & 1,9 \\
\hline $\begin{array}{l}\text { Временно неработающие, домохозяйки, находящиеся } \\
\text { в отпуске по уходу и пр. }\end{array}$ & 4,9 \\
\hline \multicolumn{2}{|c|}{ Должностной статус работающих, \% к числу ответивших } \\
\hline $\begin{array}{l}\text { Руководитель высшего звена (директор, заместитель } \\
\text { директора, главный инженер, главный специалист, } \\
\text { главный редактор, офицер и т.д.) }\end{array}$ & 11,7 \\
\hline $\begin{array}{l}\text { Руководитель среднего звена (начальник цеха, заведу- } \\
\text { ющий отделом/структурным подразделением, мастер, } \\
\text { бригадир и т.д.) }\end{array}$ & 10,7 \\
\hline $\begin{array}{l}\text { Рядовой работник (рабочий, служащий, творческий со- } \\
\text { трудник) }\end{array}$ & 39,8 \\
\hline \multicolumn{2}{|l|}{ Частота использования Интернета } \\
\hline Каждый день & 97,1 \\
\hline Один раз в два-три дня & 1,9 \\
\hline Один раз в неделю & 0 \\
\hline По мере надобности & 1,0 \\
\hline \multicolumn{2}{|c|}{ Продолжительность пребывания в Интернете } \\
\hline 1-3 часа в сутки & 31,3 \\
\hline
\end{tabular}


Вопросы теории и практики журналистики. 2017. Т. 6. № 4. С. 465-481

\begin{tabular}{|l|c|}
\hline 4-6 часов в сутки & 33,0 \\
\hline 7-9 часов в сутки & 10,7 \\
\hline Более 10 часов в сутки & 22,3 \\
\hline Зависит от потребности & 2,7 \\
\hline \multicolumn{2}{|c|}{ Цели использования Интернета } \\
\hline Делаю покупки в интернет-магазинах & 31,1 \\
\hline Знакомлюсь с новостями & 67 \\
\hline Использую Интернет как средство заработка & 9,7 \\
\hline Ищу информацию, необходимую для учебы/работы & 68,9 \\
\hline Общаюсь с друзьями в социальных сетях, блогах & 71,8 \\
\hline $\begin{array}{l}\text { Оплачиваю мобильную связь, приобретаю билеты, } \\
\text { произвожу банковские операции и пр. }\end{array}$ & 51,5 \\
\hline Пользуюсь сервисами госуслуг & 31,1 \\
\hline Посещаю сайты знакомств & 4,9 \\
\hline $\begin{array}{l}\text { Просматриваю гороскопы, сонники, информацию } \\
\text { о погоде }\end{array}$ & 14,6 \\
\hline Скачиваю игры или играю он-лайн & 12,6 \\
\hline Скачиваю музыку, песни или слушаю их он-лайн & 48,5 \\
\hline Скачиваю фильмы или смотрю их он-лайн & 48,5 \\
\hline Слушаю радио & 7,8 \\
\hline Смотрю телевизионные передачи & 29,1 \\
\hline Читаю газеты, журналы, книги & 35,0 \\
\hline
\end{tabular}

Таблица 2

\section{Самооценка респондентами уровня своей компетентности} в различных медиасферах, средняя по 5-балльной шкале

\begin{tabular}{|l|c|}
\hline \multicolumn{1}{|c|}{ Уровень компетентности } & Оценка \\
\hline $\begin{array}{l}\text { Использование возможностей поисковых интернет- } \\
\text { сервисов, грамотное формулирование запросов }\end{array}$ & 4,1 \\
\hline $\begin{array}{l}\text { Критичное восприятие информации, контента, разме- } \\
\text { щенного на различных интернет-ресурсах }\end{array}$ & 3,8 \\
\hline $\begin{array}{l}\text { Необходимость учитывать границы приватности } \\
\text { в Интернете и защищать свои приватные данные }\end{array}$ & 3,9 \\
\hline Использование цифровых и медиа-сервисов & 3,7 \\
\hline Использование сетевой коммуникации & 3,9 \\
\hline $\begin{array}{l}\text { Использование современных технических и мобильных } \\
\text { средств коммуникации }\end{array}$ & 4,1 \\
\hline Среднее, среднее специальное & 16,5 \\
\hline Высшее (незаконченное высшее) журналистское & 2,9 \\
\hline
\end{tabular}




\section{Полученные результаты}

Прежде всего, участникам опроса было предложено ответить на вопрос, какие сфреры действительности представляют для них наибольший интерес. Респонденты должны были обозначить цифрой 1 самую важную сфреру, информацию по которой они отслеживают постоянно и непрерывно; вторую по важности сфреру надо было обозначить цифрой 2 и т. д. Цифрой 10 должна быть обозначена наименее интересующая участников опроса сфрера.

Данные, приведенные в табл. 3, свидетельствуют о том, что наиболее значимой для себя респонденты считают информацию о родственниках, друзьях и знакомых. То есть первые три позиции занимают конкретные люди, которые входят в ближайшее окружение опрошенных. Зато потом идут Россия, город, в котором они живут, мир в целом. А уже за этими территориальными интересами следует информация о сослуживцах и отдельных странах (в порядке убывания): США, Франция, Китай, Германия, Украина, Великобритания, Япония, Италия, Канада, Испания, Турция, Таиланд, Сирия и др. Этот перечень свидетельствует о том, что люди считают значимой для себя информацию о странах, которые часто становятся предметом интереса СМИ; о странах, в которых живут их родственники, друзья, близкие знакомые; также о странах - потенциальных объектах туризма и отдыха. Удивительно, но ситуация в микрорайоне (если речь идет о большом городе), или в районном центре, в котором живут участники опроса, практически никакого интереса для них не представляет.

Таблица 3

\section{Значимость получения информации} по различным сферам действительности

\begin{tabular}{|l|c|c|}
\hline \multicolumn{1}{|c|}{ Сферы действительности } & $\begin{array}{c}\text { Средний } \\
\text { ранг }\end{array}$ & $\begin{array}{c}\text { Ранговое } \\
\text { место }\end{array}$ \\
\hline Родственники: муж, жена, дети, родители & 2,5 & 1 \\
\hline Близкие друзья & 2,8 & 2 \\
\hline Хорошие знакомые & 4,1 & 3 \\
\hline Россия в целом & 4,5 & 4 \\
\hline Ситуация в городе, в котором вы живете & 4,8 & 5 \\
\hline Мир в целом & 5,0 & 6 \\
\hline Сослуживцы & 5,4 & 7 \\
\hline Другие страны & 5,5 & 8 \\
\hline Ситуация в микрорайоне & 5,7 & 9 \\
\hline Ситуация в регионе (области, крае, республике) & 5,8 & 10 \\
\hline
\end{tabular}

Если сравнить эти данные с данными, характеризующими сферы интереса отдельно для мужчин и женщин, то можно обнаружить некоторые расхождения. Так, для мужчин информация о России более значима, 
чем информация о хороших знакомых; мир в целом важнее, чем ситуация в городе; информация о сослуживцах их практически не интересует. А вот женщин сослуживцы (и в скобках отметим: все, что касается их личной жизни) интересуют намного больше, чем мужчин, и этот интерес выше, чем в целом по массиву. В остальном иерархия информационных пристрастий женщин полностью совпадает со средней по массиву (табл. 4).

\section{Значимость получения информации}

Таблица 4

по различным сферам действительности для мужчин и женщин, ранговое место

\begin{tabular}{|l|c|c|}
\hline \multicolumn{1}{|c|}{ Сферы действительности } & Мужчины & Женщины \\
\hline Родственники: муж, жена, дети, родители & 1 & 1 \\
\hline Близкие друзья & 2 & 2 \\
\hline Хорошие знакомые & 4 & 3 \\
\hline Сослуживцы & 10 & 6 \\
\hline Ситуация в микрорайоне & 9 & 9 \\
\hline Ситуация в городе, в котором вы живете & 6 & 5 \\
\hline $\begin{array}{l}\text { Ситуация в регионе (области, крае, } \\
\text { республике) }\end{array}$ & 8 & 10 \\
\hline Россия в целом & 3 & 4 \\
\hline Другие страны & 7 & 8 \\
\hline Мир в целом & 5 & 7 \\
\hline
\end{tabular}

Обращаясь к рассмотрению значимости получения информации по различным сфрерам действительности для респондентов разных возрастов, прежде всего следует обратить внимание на самую старшую возрастную группу (табл. 5). Представителей этой группы в минимальной степени интересуют события мирового масштаба и жизнь сослуживцев (можно предположить, что значительная часть этих респондентов - либо неработающие пенсионеры, либо достаточно сильно погруженные в собственные дела и проблемы родных и друзей люди для того, чтобы интересоваться жизнью не очень близких людей).
Зато ситуация в городе и микрорайоне их интересует в большей степени, чем более молодых респондентов. По остальным сфрерам действительности существенных расхождений не наблюдается. Также можно отметить тот фракт, что молодые люди (22-34 года) совсем не считают для себя интересной информацию о том, что происходит в регионе их проживания.

Определенная зависимость наблюдается между интересом к разным сферам действительности и уровнем образования респондентов (табл. 6). Так, участники опроса, имеющие ученую степень, меньше, чем все остальные, интересуются 
Theoretical and Practical Issues of Journalism, 2017, vol. 6, no. 4, pp. 465-481

Значимость получения информации

Таблица 5

по различным сферам действительности для респондентов

разных возрастных групп, ранговое место

\begin{tabular}{|l|c|c|c|c|}
\hline Сферы действительности & $\begin{array}{c}\text { До 21 } \\
\text { года }\end{array}$ & $\begin{array}{c}\mathbf{2 2 - 3 4} \\
\mathbf{2 0 д a ~}\end{array}$ & $\begin{array}{c}\mathbf{3 5 - 5 5} \\
\text { лет }\end{array}$ & $\begin{array}{c}\text { Более } \\
\mathbf{5 5} \text { лет }\end{array}$ \\
\hline $\begin{array}{l}\text { Родственники: муж, жена, дети, } \\
\text { родители }\end{array}$ & 2 & 1 & 1 & 1 \\
\hline Близкие друзья & 1 & 2 & 2 & 2 \\
\hline Хорошие знакомые & 3 & 3 & 3 & 6 \\
\hline Сослуживцы & 7 & 7 & 6 & 10 \\
\hline Ситуация в микрорайоне & 10 & 9 & 10 & 5 \\
\hline $\begin{array}{l}\text { Ситуация в городе, в котором } \\
\text { вы живете }\end{array}$ & 6 & 6 & 5 & 3 \\
\hline $\begin{array}{l}\text { Ситуация в регионе (области, } \\
\text { крае, республике) }\end{array}$ & 8 & 10 & 8 & 7 \\
\hline Россия в целом & 4 & 4 & 4 & 4 \\
\hline Другие страны & 9 & 8 & 9 & 8 \\
\hline Мир в целом & 5 & 5 & 7 & 9 \\
\hline
\end{tabular}

ситуацией в микрорайоне и в городе и собственными родственниками. Зато дела сослуживцев (собратьев по науке и коллег по преподавательской деятельности) интересуют их в первую очередь. В этом они похожи на респондентов с высшим журналистским образованием, которые поставили значимость информации о сослуживцах на второе ранговое место. При этом участники опроса, имеющие журналистское образование (и - можно предположить работающие по профессии) мало интересуются другими странами, общероссийскими проблемами и ситуацией в микрорайоне. В большей степени они считают для себя значимой информацию о событиях, происходящих в мире и в городе.

Значимость получения информации

Таблица 6

по различным сферам действительности для респондентов

разных возрастных групп, ранговое место

\begin{tabular}{|c|c|c|c|c|c|}
\hline $\begin{array}{c}\text { Сферы действи- } \\
\text { тельности }\end{array}$ & $\begin{array}{c}\text { Сред- } \\
\text { нее, } \\
\text { среднее } \\
\text { специ- } \\
\text { альное }\end{array}$ & $\begin{array}{c}\text { Высшее } \\
\text { журна- } \\
\text { лист- } \\
\text { ское }\end{array}$ & $\begin{array}{c}\text { Высшее } \\
\text { гумани- } \\
\text { тарное }\end{array}$ & $\begin{array}{c}\text { Высшее } \\
\text { тесни- } \\
\text { ческое }\end{array}$ & $\begin{array}{c}\text { Ученая } \\
\text { сте- } \\
\text { пень }\end{array}$ \\
\hline $\begin{array}{l}\text { Родственники: муж, } \\
\text { жена, дети, родители }\end{array}$ & 2 & 1 & 1 & 1 & 7 \\
\hline
\end{tabular}


Вопросы теории и практики журналистики. 2017. Т. 6. № 4. С. 465-481

\begin{tabular}{|l|c|c|c|c|c|}
\hline Близкие друзья & 1 & 4 & 2 & 2 & 2 \\
\hline Хорошие знакомые & 3 & 3 & 3 & 3 & 3 \\
\hline Сослуживцы & 6 & 2 & 8 & 9 & 1 \\
\hline $\begin{array}{l}\text { Ситуация в микро- } \\
\text { районе }\end{array}$ & 8 & 9 & 9 & 7 & 10 \\
\hline $\begin{array}{l}\text { Ситуация в городе, в } \\
\text { котором вы живете }\end{array}$ & 5 & 6 & 6 & 5 & 9 \\
\hline $\begin{array}{l}\text { Ситуация в регионе } \\
\text { (области, крае, } \\
\text { республике) }\end{array}$ & 9 & 7 & 10 & 6 & 8 \\
\hline Россия в целом & 4 & 8 & 4 & 4 & 4 \\
\hline Другие страны & 10 & 10 & 7 & 10 & 6 \\
\hline Мир в целом & 7 & 5 & 5 & 8 & 5 \\
\hline
\end{tabular}

Данные, характеризующие зависимость интереса к различным сферам действительности от сферы деятельности респондентов, свидетельствуют, в частности, о том, что участники опроса, работающие в СМИ, в органах правопорядка и военные больше, чем остальные респонденты заинтересованы в получении информации о своих сослуживцах.

Должностной статус работающих респондентов также влияет на оценку значимости информации о различных сфрерах действительности. Рядовые работники в большей степени, чем руководящие интересуются делами своих сослуживцев (можно предположить, что этот интерес продиктован карьерными соображениями или технологической связанностью производственного процесса), общероссийской ситуацией и тем, что происходит в мире. Существенной разницы в информационных приоритетах руководителей высшего и среднего звена не наблюдается (табл. 7).

Значимость получения информации

Таблица 7

по различным сферам действительности для респондентов разных возрастных групп, ранговое место

\begin{tabular}{|l|c|c|c|}
\hline Сферы действительности & $\begin{array}{c}\text { Руково- } \\
\text { дители } \\
\text { высшего } \\
\text { звена }\end{array}$ & $\begin{array}{c}\text { Руководи- } \\
\text { тели сред- } \\
\text { него } \\
\text { звена }\end{array}$ & $\begin{array}{c}\text { Рядовые } \\
\text { работники }\end{array}$ \\
\hline $\begin{array}{l}\text { Родственники: муж, жена, } \\
\text { дети, родители }\end{array}$ & 1 & 1 & 1 \\
\hline Близкие друзья & 2 & 2 & 2 \\
\hline
\end{tabular}


Theoretical and Practical Issues of Journalism, 2017, vol. 6, no. 4, pp. 465-481

\begin{tabular}{|l|c|c|c|}
\hline Хорошие знакомые & 4 & 3 & 3 \\
\hline Сослуживцы & 8 & 8 & 5 \\
\hline Ситуация в микрорайне & 6 & 6 & 9 \\
\hline $\begin{array}{l}\text { Ситуация в городе, в котором } \\
\text { вы живете }\end{array}$ & 3 & 4 & 8 \\
\hline $\begin{array}{l}\text { Ситуация в регионе (области, } \\
\text { крае, республике) }\end{array}$ & 7 & 7 & 10 \\
\hline Россия в целом & 5 & 5 & 4 \\
\hline Другие страны & 9 & 10 & 7 \\
\hline Мир в целом & 10 & 9 & 6 \\
\hline
\end{tabular}

Следующий вопрос анкеты был посвящен выяснению того, какого типа информацию (описание, комментирование или анализ) респонденты заинтересованы получать о значимых для них сферах действительности. Участникам опроса было предложено обозначить цифрой 1наиболее важный для них тип сообщения; цифрой 2 - менее важный тип материала; цифрой 3 - тип материала, который для данной сферы действительности представляется им наименее важным.

Полученные данные свидетельствуют о том, что практически по всем сорерам действительности участники опроса предпочитают получать только описание событий, проблем, конфликтов и пр. И лишь о родственниках и друзьях респонденты хотели бы иметь комментарии и анализ (можно предположить, что речь идет о желании иметь оценку и объяснение различных поступков близких людей, их причин и мотивов). Что касается аналитических материалов, то в территориальном плане ими больше всего интересуются применительно к ситуациям в городе проживания и в России в целом.
Если сравнивать заинтересованность мужчин и женщин в сообщениях разных типов по поводу различных сфрер действительности, то можно обнаружить, что на первое ранговое место несколько большее количество женщин поставило ОПИCAНИЕ ситуации в микрорайоне, в городе, в регионе и в мире в целом. Что касается КОММЕНТИРОВАНИЯ, то мужчины по всем сферам действительности заинтересованы в нем больше, чем женщины. АНАЛИТИЧЕСКИЙ ПОДХОД В боЛЬшеЙ степени, чем мужчин, интересует женщин, когда речь идет о сослуживцах, хороших знакомых и друзьях.

Есть некоторая разница в заинтересованности респондентов с разным должностным статусом. Так, например, руководителей среднего звена в большей степени интересует ОПИСАНИЕ событий, проблем, конфликтов, относящихся, с одной стороны, к родственникам, а с другой - происходящих в России и других странах мира. В КОММЕНТАРИЯХ по поводу ситуаций, в которые попадают близкие друзья, а также по поводу того, что происходит в микрорайоне и в России, в большей степени заинтересованы руководи- 
тели высшего звена. Они же чаще всего интересуются АНАЛИЗОМ действий родственников и друзей.

Некоторым образом влияет на пристрастия к разным типам сообщений и возраст респондентов. Например, люди старше 55 лет чаще представителей других возрастных групп предпочитают получать АНАЛИЗ действий родственников, друзей и сослуживцев. А вот в КОММЕНТАРИЯХ по тем же группам больше заинтересованы участники опроса в возрасте до 21 года.

\section{Выводы}

Таким образом, полученные данные позволяют сделать предварительный вывод о том, что личная повестка дня представляет собой значительно более сложное явление, нежели это описывается в существующих на сегодняшний день концептуальных наработках. Она формируется индивидом в процессе активного взаимодействия с массивом данных, предлагаемых медиа. Однако в сознании индивида есть исходная, довольно жесткая матрица, обеспечивающая и отбор, и иерархизацию сведений, поступающих из массмедиа и других источников.

Это означает, что любая повестка дня, которую СМИ вводят в общественный оборот, на уровне индивидуального сознания переструктурируется. Каждое событие, каждая проблема, заявляемые СМИ в качестве важных, получают в сознании индивида свой «индекс важности», чаще всего не совпадающий с навязываемыми индексами. Вполне вероятно, что эти информационные приоритеты выступают в роли защитных фильтров, оберегающих индивида от манипулятивного воздействия СМИ.

Данные устойчивые приоритеты личности связаны с принадлежностью к определенной религиозной, профессиональной, этнической группе, социальным статусом, психологическими особенностями и некоторыми другими фракторами, которые нуждаются в отдельном исследовании. Однако для более глубокого подтверждения и развития этих положений необходимы масштабные исследования.

\section{СПИСОК ИСПОЛЬЗОВАННОЙ ЛИТЕРАТУРЫ}

1. Липпман У. Общественное мнение / У. Липпман. - М. : Институт Фонда «Общественное мнение», 2004. - 384 с.

2. Long N. E. The local community as an ecology of games / N. E. Long // American Journal of Sociology. - 1958. - 64 p.

3. Lang K. The Mass Media and Voting / K. Lang, G. Lang // Reader in Public Opinion and Communication ; ed. B. Berelson, M. Janowitz. - New York : Columbia University Press, 1966.

4. Lazarsfeld P. The People Choice / P. Lazarsfeld, B. Berelson, H. Gaudet. — New York : Columbia University Press, 1948.

5. Klapper J. T. The effects of mass communication / J. T. Klapper. - New York : FreePress, 1960.

6. Zaller J. The myth about massive effect of media revived? New support of

discredited idea / J. Zaller //Political persuasion and attitudes change. - 1996. Pp. 17-78.

7. McCombs M. E. The agenda-setting function of mass media / M. E. McCombs, D. L. Shaw // Public opinion quarterly. - 1972. - Vol. 36, no 2. 
8. McCombs M. E. New Directions in Agenda-Setting Theory and Research / M. E. McCombs, D. L. Shaw, D. H. Weaver // Mass Communication \& Society. - 2014. No. 17. - Pp. $781-802$.

9. McCombs M. Setting the Agenda: The Mass Media and Public Opinion / M. McCombs. Cambridge: Polity, 2014.

10. Дьякова Е. Г. Массовая политическая коммуникация в теории установления повестки дня: от эффекта к процессу / Е. Г. Дьякова // Политические исследования. 2003. - № 3. - С. 109-119.

11. Хилгартнер С. Рост и упадок социальных проблем: концепция публичных арен [Электронный ресурс] / С. Хилгартнер, Ч. Л. Боек. - Режим доступа: http://'socreal.fom.m/ files/sr0802-073-094.pdf

12. Albig W. Public Opinion / W. Albig. - Sturgis: Sturgis Press, 2007.

13. Lim A. A. Cross-Lagged Analysis of Agenda Setting Among Online News Media / A. A. Lim // Journalism and Mass Communication Quarterly. - 2006. - Vol. 83, no. 2. - Pp. 298-312.

14. Луман Н. Реальность масс-медиа / Н. Луман. - М. : Праксис, 2005. - 256 с.

15. Маклюэн М. Понимание медиа / М. Маклюэн. - 3-е изд. - М. : Кучково поле, 2017. $-463 \mathrm{c}$. 1994.

16. McQuail D. Mass Communication Theory: An Introduction / D. McQuail. —London,

17. Бурдье П. О телевидении и журналистике / П. Бурдье. - М. : Прагматика культуры, 2002. - 160 с.

18. Епифанова М. Россия тонет в телеволнах / М. Епифанова // Новая газета. 2014. - № 66.

19. Козлов С. В. Роль средств массовой коммуникации в установлении повестки дня «оранжевой революции» / С. В. Козлов // Вестник НГУ. Серия «История, фрилология». 2010. - Т. 9, Вып. 6. - С. 73.

20. Иванова Т. Стратегическая матрица России / Т. Иванова // Экономические стратегии. - 2009. — № 1. - С. 124-130.

21. Кара-Мурза С. Г. Русская матрица: Будет ли перезагрузка? / С. Г. Кара-Мурза. М. : Эксмо, 2012. - 240 с.

22. Никонов В. А. Российская матрица / В. А. Никонов. - М. : Русское слово, 2014. 992 c.

23. Дзялошинский И. М. Коммуникационные матрицы прикладной политической коммуникативистики / И. М. Дзялошинский // Политическая коммуникативистика: теория, методология и практика. - М. : РАПН-РОССПЕН, 2012. - С. 42-58.

24. Дзялошинский И. М. Коммуникационные процессы в обществе: институты и субъекты / И. М. Дзялошинский. - М. : АПК и ППРО, 2012. - 461 с.

25. Дзялошинский И. М. К вопросу о понятийном аппарате медиаисследований / И. М. Дзялошинский, М. И. Дзялошинская // Медиаскоп. — 2014. —№ 4. —С. 24.

\section{REFERENCES}

1. Lippmann W. Obshchestvennoe mnenie [Public Opinion]. Moscow, Public opinion Publ., 2004. 384 p.

2. Long N. E. The local community as an ecology of games. American Journal of Sociology, 1958, $64 \mathrm{p}$.

3. Lang K. The Mass Media and Voting. Reader in Public Opinion and Communication; ed. B. Berelson, M. Janowitz. New York, Columbia University Press, 1966.

4. Lazarsfeld P., Berelson B., Gaudet H. The People Choice. New York, Columbia University Press, 1948.

5. Klapper J. T. The effects of mass communication. New York, FreePress, 1960.

6. Zaller J. The myth about massive effect of media revived? New support of discredited idea. Political persuasion and attitudes change. 1996. Pp. 17-78.

7. McCombs M. E., Shaw D. L. The agenda-setting function of mass media. Public opinion quarterly, 1972, vol. 36, no 2. 
8. McCombs M. E., Weaver D. H., Shaw D. L. New Directions in Agenda-Setting Theory and Research. Mass Communication \& Society, 2014, no. 17, pp. 781-802.

9. McCombs M. Setting the Agenda: The Mass Media and Public Opinion. Cambridge, Polity, 2014.

10. D'yakova E. G. Political Mass Communication in the Theory of Establishing an Agenda: from the Effect to the Process. Politicheskie issledovaniya = Political Studies, 2003, no 3, pp. 109-119. (In Russian).

11. Hilgartner S., Boek. Rost i upadok social'ny h problem: koncepciya publichnyh aren [Increase and Decrease of Social Problems: Public Arenas Concept]. Available at: http://'socreal. fom.m/files/sr0802-073-094.pdf

12. Albig W. Public Opinion. Sturgis, Sturgis Press, 2007.

13. Lim A. A. Cross-Lagged Analysis of Agenda Setting Among Online News Media. Journalism and Mass Communication Quarterly, 2006, vol. 83, no. 2, pp. 298-312.

14. Luman N. Real'nost' mass-media [The Mass Media Reality]. Moscow, Praksis Publ., 2005. 256 p.

15. Maklyuehn M. Ponimanie media [Understanding of the Media]. Moscow, Kuchkovo pole, 2017. $463 \mathrm{p}$.

16. McQuail D. Mass Communication Theory: An Introduction. London, 1994.

17. Burd'e P. O televidenii i zhurnalistike [On Television and Journalism]. Moscow, Pragmatika kul'tury Publ., 2002. 160 p.

18. Epifanova M. Russia is drowning in televolna. Novaya gazeta = The New Newspaper, 2014, no. 66. (In Russian).

19. Kozlov S. V. The role of the media in setting the agenda of the "orange revolution». Vestnik NGU. Seriya "Istoriya, filologiya» = Bulletin of Novosibirsk State University. Series «History, Philology», 2010, vol. 9, Iss. 6, pp. 73. (In Russian).

20. Ivanova T. Strategicheskaya matrica Rossii. Ehkonomicheskie strategii $=$ Economic Strategies, 2009, no. 1, pp. 124-130. (In Russian).

21. Kara-Murza S. G. Russkaya matrica: Budet li perezagruzka? [The Russian Matrix: Will it be Reloaded?]. Moscow, Ehksmo Publ., 2012. 240 p.

22. Nikonov V. A. Rossijskaya matrica [The Russian Matrix]. Moscow, Russkoe slovo Publ., 2014. 992 p.

23. Dzialoshinskiy I. M. Communication Matrices of Applied Political Communication Science. In Politicheskaya kommunikativistika: teoriya, metodologiya i praktika [Political Communication Science: Theory, Methodology and Practice]. Moscow, RAPN-ROSSPEN Publ., 2012, pp. 42-58. (In Russian)

24. Dzialoshinskiy I. M. Kommunikacionnye processy v obshchestve: instituty $i$ sub"ekty [Communication Processes in Society: Insitutions and Subjects]. Moscow, APK i PPRO Publ., 2012. $461 \mathrm{p}$.

25. Dzialoshinskiy I. M., Dzyaloshinskaya M. I. To the issue of conceptual apparatus of media studies. Mediaskop = Mediascope, 2014, no 4, pp. 24. (In Russian).

\section{ДЛЯ ЦИТИРОВАНИЯ}

Дзялошинский И. М. Личная повестка дня: исследуем приоритеты аудитории / И. М. Дзялошинский, М. И. Дзялошинская // Вопросы теории и практики журналистики. — 2017. — Т. 6, № 4. — С. 465-481. DOI: 10.17150/2308-6203.2017.6(4).465-481.

\section{FOR CITATION}

Dzialoshinskiy I. M., Dzyaloshinskaya M. I. Personal Agenda: Studying Audience Priorities. Voprosy teorii i praktiki zhurnalistiki = Theoretical and Practical Issues of Journalism, 2017, vol. 6, no. 4, pp. 465-481. DOI: 10.17150/2308-6203.2017.6(4).465-481. (In Russian). 